 \\ Invertebrate Reproduction \& Development
}

\section{Insights of the life history in the porcellanid crab Petrolisthes armatus (Gibbes, 1850) (Crustacea: Anomura: Porcellanidae) from the Southwestern Atlantic coast}

Marcelo Antonio Amaro Pinheiro, Marcio Camargo Araujo João, Maria Helena Arruda Leme, Akeme Milena Ferreira Matsunaga, Juliana Priscila Piva Rio \& Patricio Hernáez

To cite this article: Marcelo Antonio Amaro Pinheiro, Marcio Camargo Araujo João, Maria Helena Arruda Leme, Akeme Milena Ferreira Matsunaga, Juliana Priscila Piva Rio \& Patricio Hernáez (2017) Insights of the life history in the porcellanid crab Petrolisthes armatus (Gibbes, 1850) (Crustacea: Anomura: Porcellanidae) from the Southwestern Atlantic coast, Invertebrate Reproduction \& Development, 61:2, 78-89, DOI: 10.1080/07924259.2017.1285818

To link to this article: https://doi.org/10.1080/07924259.2017.1285818

Published online: 16 Feb 2017.

Submit your article to this journal $\pi$

Цلll Article views: 135

Q View related articles $\sqsubset$

View Crossmark data 


\title{
Insights of the life history in the porcellanid crab Petrolisthes armatus (Gibbes, 1850) (Crustacea: Anomura: Porcellanidae) from the Southwestern Atlantic coast
}

\author{
Marcelo Antonio Amaro Pinheiro ${ }^{\mathrm{a}, \mathrm{b}}$, Marcio Camargo Araujo João ${ }^{\mathrm{a}, \mathrm{b}}$, Maria Helena Arruda Leme $\mathrm{e}^{\mathrm{b}, \mathrm{c}}$, \\ Akeme Milena Ferreira Matsunaga a,b, Juliana Priscila Piva Rio ${ }^{\mathrm{a}, \mathrm{b}}$ and Patricio Hernáez $z^{\mathrm{b}, \mathrm{d}}$ \\ anstituto de Biociências (IB), UNESP - Univ Estadual Paulista, Campus do Litoral Paulista (CLP), São Vicente, Brazil; ${ }^{b}$ Grupo de Pesquisa em \\ Biologia de Crustáceos (CRUSTA), Laboratório de Biologia de Crustáceos (LBC), Brazil; ' Instituto de Ciências e da Saúde, UNIP - Universidade \\ Paulista, Campus SJC, São José dos Campos, Brazil; ' ${ }^{F}$ acultad de Ciencias, Departamento de Biología, Centro de Estudios Marinos y Limnológicos, \\ UTA - Universidad de Tarapacá, Arica, Chile
}

\begin{abstract}
Petrolisthes armatus (Gibbes, 1850) life history was evaluated based on growth and reproduction. Specimens were captured at Ubatuba (Brazil), identified, sexed and measured: carapace $(\mathrm{CL}$, length; CW, width), larger cheliped propodus ( $\mathrm{PL}$, length; PW, width; and $\mathrm{PH}$, height), and 2th and 5th abdominal somite ( $\mathrm{AW}_{2}$ and $\mathrm{AW}_{5}$, width). Relative growth was studied using $\mathrm{CL}$ as independent variable and its relation with other variables (dependents), to estimate puberty size and morphological maturity. Fecundity was represented by number of eggs vs. body size CL, with a better fit using a power function. Considering the 257 specimens analyzed, males were larger than females, and the overall sex ratio was 1:1, with some differences among size classes. Maturity (puberty size) was revealed by: $\mathrm{AW}_{2} \times \mathrm{CL}$ (males: $8.6 \mathrm{~mm} \mathrm{CL}$; females: $7.6 \mathrm{~mm} \mathrm{CL}$ ); and $\mathrm{AW}_{5} \times \mathrm{CL}$ (7.1 and $7.6 \mathrm{~mm} \mathrm{CL}$, respectively). Reproduction was continuous, but more intense in rainy season and recruitment occurring in dry season. Fecundity of this species was $228 \pm 163$ eggs, with better fit by a power function $\left(R^{2}=0.72\right)$. Maturity size and growth differed when a pristine area (Ubatuba) was compared with a polluted area (São Sebastião), in the same Brazilian area (São Paulo State).
\end{abstract}

\section{ARTICLE HISTORY}

Received 17 August 2016

Accepted 18 January 2017

\section{KEYWORDS}

Fecundity; maturity; population biology; relative growth; reproduction

\section{Introduction}

The porcellanid crab Petrolisthes armatus (Gibbes, 1850) is one of the most common anomuran crabs along the Western Atlantic coast of the Americas (Werding et al. 2003). Its geographical distribution covers a wide range of latitudes on Western Atlantic (North Carolina, USA to Brazil), Eastern Atlantic (Senegal to Angola, Ascension Island) and Eastern Pacific coast (Gulf of California, USA to Peru) (Melo 1999 and references therein). Due to this wide geographical distribution, $P$. armatus was considered for a long time as a complex of different species (Werding et al. 2003). However, a recent morphological and genetic study demonstrated that there is no evidence of a $P$. armatus species complex along the American coast (Mantelatto et al. 2011). Therefore, the large population of P. armatus along the southwestern Atlantic coast should be considered as a metapopulation (i.e. group of spatially separated populations which interact at some level, according to Levins 1969).

Most of the studies about P. armatus have been conducted in Brazilian coast allowing a collection of information about different life-history traits of this species. Among them, there are a series of studies covering several aspects of this species such as population structure, sexual maturity, relative growth, sex ratio, breeding cycle, and larval/adult density (see Oliveira \& Masunari 1995; Miranda \& Mantelatto 2009, 2010; Oliveira et al. 2013), which supported the use of this species as bioindicator of water quality in marine biotopes (Nicol 1932; Caine 1975; Micheletti-Flores \& Negreiros-Fransozo 1999). However, features of the life history might change with a wide latitudinal distribution of $P$. armatus, a fact confirmed by other studies on body size (Atkinson \& Sibly 1997; Angilletta \& Dunham 2003; Hernáez 2014) and reproductive biology (Hernáez 2001, 2014; Defeo \& Cardoso 2002; Brante et al. 2004; Rivadeneira et al. 2010).

Like other decapod crustaceans, P. armatus has three postembryonic phases (larval, juvenile, and adult) and transitions among them can be identified (Hartnoll 1974, 1978, 1982; Miranda \& Mantelatto 2010). Biometry allows the estimation of brachyuran puberty size using some sexual characters, such as chelar propodus and abdominal 


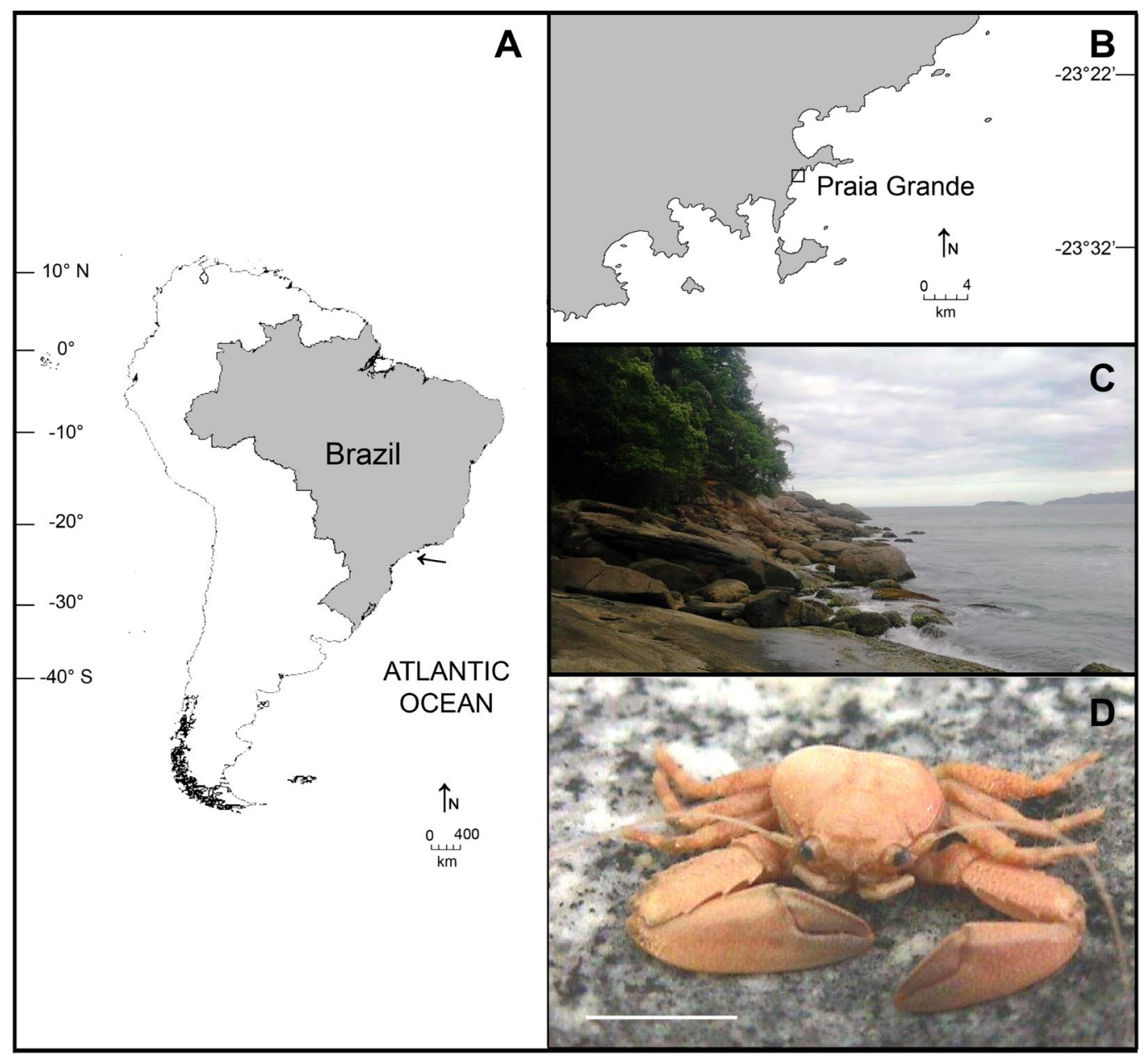

Figure 1. Map of the South America (A), with a geographical detail of the studied area (B); general view of the intertidal north rocky coast of 'Praia Grande' beach (C), Ubatuba, São Paulo State, Brazil; and antero-superior view of an exemplar (male) of Petrolisthes armatus (D). (Source: Author).

Note: The size of the scale bar is $10 \mathrm{~mm}$.

segments (Pinheiro \& Fransozo 1993). In some crustaceans, these morphological changes are essential to attain sexual maturity (Petriella \& Boschi 1997; Souza-Carvalho et al. 2011) and can be revealed by relative growth analysis (Pinheiro \& Hattori 2006; Miranda \& Mantelatto 2010). In carcinology, this subject is common with species of Brachyuran infraorder (Hartnoll 2001), but a lag is verified with those for Anomuran infraorder, where only a few articles are available about sexual dimorphism (Biagi \& Mantelatto 2006; Miranda \& Mantelatto 2010; Ferreira 2015).

In this study, we are particularly interested in looking at the population structure, sex ratio as a function of size, relative growth, size at sexual maturity, recruitment intensity, and breeding patterns of $P$. armatus from Northern coast of São Paulo State, Brazil. This kind of information will provide an insight into the life-history traits of this species, comparing our results with those from other porcellanid crabs in order to improve our understanding of population dynamics in marine invertebrates from subtropical regions.

\section{Material and methods}

\section{Study area and sampling of crabs}

Specimens of $P$. armatus were monthly collected by hand during low tides from August 1996 to July1997 at intertidal

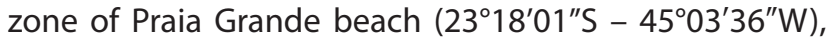
Ubatuba, Northern coast of São Paulo State, Brazil (Figure 1). Specimens were hand collected under rocks along this rocky coast by three people during one hour. This capture effort ( $3 \mathrm{~h} /$ month) was the same previously tested by Miranda and Mantelatto $(2009,2010)$ and considered optimum to minimize bias promoted by variability of sampling. This procedure allows different representative sizes of small and adult crabs to be caught in this population. 
Animals were carefully rinsed with seawater, placed in a plastic bag and preserved into $70 \%$ ethanol until transport to laboratory, where samples were washed with freshwater over a $0.25 \mathrm{~mm}$ sieve before sorting. Additionally, we obtained monthly water temperature $\left(\mathrm{WT}, \pm 0.1{ }^{\circ} \mathrm{C}\right)$ and rainfall $(\mathrm{mm})$ from the dataset of 'Instituto Nacional de Meteorologia' Brazil, while photoperiod data were obtained according to VarejãoSilva and Ceballos (1982), using latitude at the study area (23⒈ $\left.18^{\prime} 01^{\prime \prime} \mathrm{S}\right)$.

In the laboratory, each crab was identified according to the key for Western Atlantic Porcellanidae of Haig (1956), and the description of $P$. armatus published by Melo (1999). Males have a well-developed gonopods (2th pleomere) and gonopores at the coxae of the 5th pair of pereopods, while females have three paired setose pleopods (3-5th pleomeres) and gonopores at the base of the 3rd pair of pereopods (Osawa \& Mclaughlin 2010). Measurements were taken from all collected crabs under a stereomicroscope (Zeiss ${ }^{\circ}$ Stemi ${ }^{\circ}$ SV-6): carapace length $(C L$, from rostrum tip to the posterior margin of the carapace); carapace width $(\mathrm{CW}$, the widest measure between the lateral margins of the carapace); length, width, and height of the largest propodus ( $\mathrm{PL}, \mathrm{PW}$, and $\mathrm{PH}$, respectively); and width of the second $\left(W_{2}\right)$ and fifth $\left(W A_{5}\right)$ abdominal somites. Lastly, each female crab was classified according to the presence or absence of embryos carried beneath the pleon (brooding or non-brooding, respectively).

\section{Sexual dimorphism, population structure, and sex ratio}

Sexual dimorphism in P. armatus was checked by comparison of the average $\mathrm{CL}$ between each sex using a $t$-test or Mann-Whitney $(U)$, according to homo or heterogeneity, of the variances respectively (Zar 2010). To examine the overall size frequency distribution of $P$. armatus, a sizefrequency histograms of the $C L$ was constructed to each sex with $1 \mathrm{~mm}$ size classes, with inclusion of brooding females frequency. The normal component of each sex was separated by Bhattacharya method and confirmed by NormSep routine (see FISAT software - Gayanilo et al. 1996), with identification of each modal component and mean to each cohort.

Sex ratio along ontogeny was analyzed for $P$. armatus to verify the ratio between sexes and compare with natural ratio (1:1), as a function of size using the patterns proposed by Wenner (1972). For this purpose, sex ratio was estimated as the number of males divided by the total number of individuals in each size class $(1 \mathrm{~mm})$ and tested for deviations from an expected 1:1 sex ratio using a binomial test (Wilson \& Hardy 2002).

\section{Relative growth and sexual maturity}

In Anomuran crabs (Porcellanidae), one of the most noticeable characters is the strong tendency toward asymmetry (e.g. chelipeds in males and pleomeres, in females) (McLaughlin 1980). Each dependent body variable (CW, carapace width; PL, PW, and PH, chelar propodus length, width, and height, respectively; and $\mathrm{AW}_{2}-\mathrm{AW}_{5^{\prime}}$ abdominal width of the second and fifth somite, also respectively) was related to body size as an independent variable CL. Empirical points were fitted by a power function $Y=a X^{b}$ (Hartnoll 1978, 1982) using the coefficient of determination $\left(R^{2}, p<0.05\right)$, and the allometric growth was established by constant ' $b$ ' (see Somerton 1980). Data were also submitted to the same procedures indicated by Somerton (1980) and Somerton and Macintosh (1983), to identify the size at maturity. The 'segmented' package of ' $R$ ' software - Version 2.5.0 (Ihaka \& Gentleman 1996) was used to identify possible break point(s) during ontogeny (puberty size), in males and females, revealing the morphological dimorphism between the developmental stages (juvenile and adult). In each case, the allometric growth rate ('b') was established as isometric $(b=1)$, positive allometric $(b>1)$ or negative allometric $(b<1)$, using a $t$-test to verify a possible difference of $b$-value from the unit $(\alpha=0.01)$. To confirm one or two regression lines for empirical point of each regression analysis, we used a Snedecor's F-test ( $\alpha=0.01$ ) (Sokal \& Rohlf 1995), as recommended by Pinheiro and Fransozo (1993). Crabs with missing claws or limbs were excluded from the allometric analyses.

\section{Dynamics of reproduction and recruitment}

According to Alvares et al. (2013), South and Southeast Brazilian regions have two well-defined climatic seasons: a dry season (May to October) and a rainy season (November to April). This criterion was used to evaluate possible differences in relation to body size, reproductive activity and intensity of recruitment for $P$. armatus. The proportion of brooding females was estimated as the number of females carrying eggs relative to the total number of females for each season (i.e. excluding juvenile females). Recruitment intensity was described by the presence of small individuals below $5 \mathrm{~mm} \mathrm{CL}(=5$ th percentile) obtained from the size-frequency histogram of the total crabs collected during the study period (Hernáez \& Wehrtmann 2007). We compared the proportion of ovigerous females and recruits among periods using chisquare test and Marascuilo procedure ( $\alpha=0.05)$, verifying possible contrasts between and within multinomial proportions (Marascuilo \& McSweeney 1977). 


\section{Influence of environmental parameters on reproduction}

To evaluate the importance of each environmental parameter (water temperature, rainfall, photoperiod and season) on breeding pattern and intensity of recruitment of $P$. armatus (as informed by Sastry 1983), a stepwise multiple regression analysis was used. Regression analysis was implemented with monthly values of each numeric variable. The parameters of the model $\left(\beta_{0}\right.$ : constant, $\beta_{1}$ : water temperature, $\beta_{2}$ : rainfall, $\beta_{3}$ : photoperiod, $\beta_{4}$ : season) were obtained through the least square method (Zar 2010). Non-significant predictor variables were removed from the final model. The different assumptions of the multiple regression (i.e. normality of the dependent variable, linearity of predictor variables, homoscedasticity, and independence of residuals) were previously tested before running the analysis.

\section{Fecundity vs. body size}

A total of 83 ovigerous females were used to estimate fecundity in $P$. armatus. For this purpose, egg mass was gently detached with forceps from the pleopods of each ovigerous female, embryonic phase established according Hattori and Pinheiro (2001), and the total egg number (EN) of ovigerous females with initial embryonic stages registered in a manual counter under the stereomicroscope (Zeiss ${ }^{\circ}$ Stemi ${ }^{\circ}$ SV-6). Fecundity was obtained through the relationship of the number of egg (NE) vs. CL, with previous outliers removal by Studentized residuals' method. The scatter data were subjected to regression analyses using a power function $Y=a X^{b}$ (Hartnoll 1978, 1982), which has been previously used in other porcellanid crab species (e.g. Hattori \& Pinheiro 2001; Hernáez \& Palma 2003). The $b$-value of the $E N x C L$ relationship was categorized as isometric $(b=3)$, positive allometric $(b>3)$, or negative allometric $(b<3)$ (Somers 1991). Lastly, departures from isometry were tested using independent Student's $t$-tests (Zar 2010).

\section{Results}

\section{Sexual dimorphism, population structure, and sex ratio}

During this study, 257 specimens of $P$. armatus were captured, comprising 118 males (45.9\%) and 139 females (54.1\%), including 83 egg-bearing females. The body size $\mathrm{CL}$ of males varied between 4.0 and $14.1 \mathrm{~mm}$ (mean $\pm \mathrm{SD}$, $8.7 \pm 2.4 \mathrm{~mm}$ ), while for females varied between 4.4 and $10.3 \mathrm{~mm}(7.8 \pm 1.39 \mathrm{~mm})$. Ovigerous females ranged from 5.1 to $10.3 \mathrm{~mm} \mathrm{CL}(8.1 \pm 1.2 \mathrm{~mm})$. Males were significantly larger than females $(U=10,354.5, p=0.001)$.

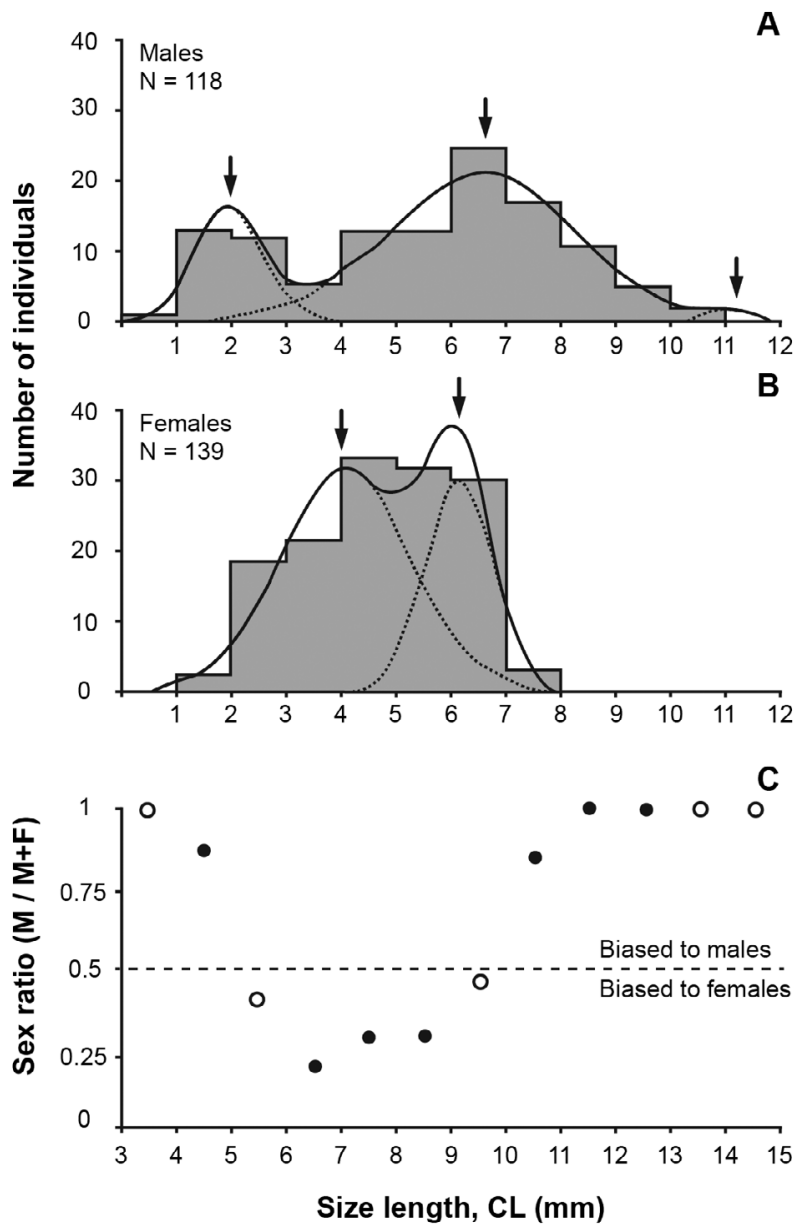

Figure 2. Size-frequency distribution of each sex of Petrolisthes armatus (A, males; and B, females); and sex ratio as a function of size (C) at 'Praia Grande, Ubatuba, São Paulo State, Brazil.

Note: Sample size and average ( \pm standard deviation) of the body size (CL) to each population category (males, females without eggs and ovigerous females).

The size structure was asymmetric for both sexes, biased toward smaller individuals in males and females (average $<<$ median). Modal progression analysis revealed the presence of three cohorts in males and two cohorts in females (Figure 2A, B).

Overall sex ratio did not differ significantly from 1:1 in the population of $P$. armatus, with a sex ratio proportion of $0.459\left(X^{2}=1.72, p>0.05\right)$. Males were more abundant than females in size class smaller than $5.0 \mathrm{~mm} \mathrm{CL}$ ( 14 males and 2 females), and between 10.1 and $15.0 \mathrm{~mm} \mathrm{CL}$, with a sex ratio biased toward females between 5.1 and $10.0 \mathrm{~mm}$ $\mathrm{CL}$ (Figure 2C).

\section{Relative growth and sexual maturity}

All relationships have significant positive correlation $(p<0.001$; Table 1$)$ between the variables. No discernible $b$-value change was confirmed when $\mathrm{CW}$ and propodus dimensions ( $\mathrm{PL}, \mathrm{PW}$, and $\mathrm{PH}$ ) were related to 
Table 1. Relative growth in Petrolisthes armatus with reference to regression equations, their coefficients of determination $\left(R^{2}\right)$, test to confirmation of one/two line regressions ( $F$ Snedecor), and test to confirm allometric level ( $t$-test), categorizing isometry ( 0$)$, negative allometry (-) and positive allometry (+). Relationships were based on biometric variables of carapace $(\mathrm{CL}$, length; $\mathrm{CW}$, width), major chelar propodus (PL, length; $\mathrm{PW}$, width; and $\mathrm{PH}$, height) and abdominal width ( $\mathrm{AW}_{2}$, second somite; and $\mathrm{AW}_{5^{\prime}}$, fifth somite).

\begin{tabular}{|c|c|c|c|c|c|c|c|c|}
\hline Dependent variable & Sex & Stage & N & Equation $\left(Y=a X^{b}\right)$ & $R^{2}$ & F Snedecor & $t$-test & Allometric level \\
\hline \multirow[t]{2}{*}{$\overline{C W}$} & Male & Total & 117 & $\mathrm{CW}=0.905 \mathrm{CL}^{1.01}$ & $0.99^{*}$ & $5.40^{\mathrm{ns}}$ & $1.15^{\mathrm{ns}}$ & 0 \\
\hline & Female & Total & 136 & $\mathrm{CW}=0.845 \mathrm{CL}^{1.06}$ & $0.98^{*}$ & $8.05^{\mathrm{ns}}$ & $4.54^{*}$ & + \\
\hline \multirow[t]{2}{*}{$P L$} & Male & Total & 94 & $\mathrm{PL}=0.798 \mathrm{CL}^{1.31}$ & $0.98^{*}$ & $9.85^{\mathrm{ns}}$ & $14.30^{*}$ & + \\
\hline & Female & Total & 110 & $\mathrm{PL}=0.963 \mathrm{CL}^{1.19}$ & $0.94^{*}$ & $6.45^{\mathrm{ns}}$ & $7.08^{*}$ & + \\
\hline \multirow[t]{2}{*}{ PW } & Male & Total & 95 & $\mathrm{PW}=0.153 \mathrm{CL}^{1.29}$ & $0.95^{*}$ & $7.40^{\mathrm{ns}}$ & $12.50^{*}$ & + \\
\hline & Female & Total & 106 & $P W=0.192 C L^{1.14}$ & $0.88^{*}$ & $8.00^{\mathrm{ns}}$ & $6.53^{*}$ & + \\
\hline \multirow[t]{2}{*}{$\mathrm{PH}$} & Male & Total & 94 & $\mathrm{PH}=0.242 \mathrm{CL}^{1.41}$ & $0.90^{*}$ & $9.90^{\text {ns }}$ & $6.55^{*}$ & + \\
\hline & Female & Total & 112 & $\mathrm{PH}=0.298 \mathrm{CL}^{1.30}$ & $0.76^{*}$ & $8.05^{\mathrm{ns}}$ & $2.27^{*}$ & + \\
\hline \multirow{4}{*}{$\mathrm{AW}_{2}$} & Male & Juvenile & 48 & $\mathrm{AW}_{2}=0.664 \mathrm{CL}^{1.00}$ & $0.95^{*}$ & $8.60^{*}$ & $0.01^{\mathrm{ns}}$ & 0 \\
\hline & & Adult & 69 & $\mathrm{AW}_{2}^{2}=0.866 \mathrm{CL}^{0.88}$ & $0.92^{*}$ & & $3.94^{*}$ & - \\
\hline & Female & Juvenile & 54 & $\mathrm{AW}_{2}^{2}=0.482 \mathrm{CL}^{1.23}$ & $0.86^{*}$ & $7.60^{*}$ & $3.34^{*}$ & + \\
\hline & & Adult & 84 & $\mathrm{AW}_{2}^{2}=0.860 \mathrm{CL}^{0.95}$ & $0.68^{*}$ & & $0.72^{\mathrm{ns}}$ & 0 \\
\hline \multirow{4}{*}{$\mathrm{AW}_{5}$} & Male & Juvenile & 29 & $\mathrm{AW}_{5}^{2}=0.681 \mathrm{CL}^{1.01}$ & $0.91^{*}$ & $7.10^{*}$ & $0.20^{\mathrm{ns}}$ & 0 \\
\hline & & Adult & 88 & $\mathrm{AW}_{5}^{3}=0.861 \mathrm{CL}^{0.90}$ & $0.94^{*}$ & & $4.31^{*}$ & - \\
\hline & Female & Juvenile & 52 & $\mathrm{AW}_{5}^{5}=0.467 \mathrm{CL}^{1.29}$ & $0.86^{*}$ & $7.55^{*}$ & $3.83^{*}$ & + \\
\hline & & Adult & 85 & $\mathrm{AW}_{5}^{3}=0.888 \mathrm{CL}^{0.97}$ & $0.68^{*}$ & & $0.40^{\mathrm{ns}}$ & 0 \\
\hline
\end{tabular}

${ }^{*} p<0.05 ;{ }^{\text {ns }} p>0.05$.

the independent variable $C L$ for both sex of $P$. armatus (Snedecor test). In contrast, the equations involving abdominal variables $\left(\mathrm{AW}_{2}\right.$ and $\left.\mathrm{AW}_{5}\right)$ vs. $\mathrm{CL}$ showed differences in $b$-value along the ontogeny of males and females.

The pattern of relative growth to $C W x C L$ relationship differed between sexes, with males presenting an isometric growth $(b=1.01, p>0.05)$, while a positive allometry was confirmed for females $(b=1.06, p<0.05)$. All relationships involving measurements of the chelar propodus (PL, PW, and $\mathrm{PH}$ ) in relation to body size $\mathrm{CL}$, indicated a positive allometry $(p<0.001)$ for both sexes, with a higher degree in males $(1.29<b<1.41)$ when compared with females $(1.14<b<1.30)$, but not confirmed during ontogeny of each sex. Otherwise, relationships involving abdominal variables by $C L\left(A W_{2} \times C L\right.$ and $\left.A W_{5} \times C L\right)$ revealed an allometric degree change during ontogeny, confirming two phase lines (jv, juvenile; and ad, adult). Both sex showed a reduction of allometric degree between these phases, less pronounced in males $\left(b_{\mathrm{jv}}-b_{\mathrm{ad}}=0.11-0.12\right)$ than females $\left(b_{j v}-b_{a d}=0.28-0.32\right)$, but with a change of relative growth from positive allometry to isometry in females (Figure 3, right panel) and isometry to negative allometry in males (Figure 3, left panel). Puberty size in females was $7.6 \mathrm{~mm}$ CL for both relationships involving abdominal variables, but in males, the puberty was detected between $7.1 \mathrm{~mm} \mathrm{CL}\left(\mathrm{AW}_{5}\right)$ and $8.6 \mathrm{~mm} \mathrm{CL}\left(\mathrm{AW}_{2}\right)$. Considering the best estimate of size at sexual maturity in males and females, the population of $P$. armatus consisted mainly of adults (60\%), with a minor frequency of juveniles (i.e. including recruits) in the overall sample.

\section{Dynamics of reproduction and recruitment}

Males were significantly larger than females $(U=3927.50$, $p=0.0001$ ) during rainy season but no during dry season
$(U=1524.0, p=0.808$; Figure 4A). Egg-bearing female of $P$. armatus were found almost continuously throughout the year $(N=83)$; however, a significantly higher number of ovigerous females ( $p<0.001$ ) were found during rainy season (76\%) compared to dry season (34\%, Figure 4B). Recruitment intensity showed an inverse seasonal pattern, significantly higher during dry season (14\%) than during rainy season (1\%) (Figure $4 \mathrm{C}$ ).

\section{Influence of environmental parameters on reproduction}

During dry season, water temperature ranged from $24.1 \pm 3.0$ to $25.9 \pm 2.53{ }^{\circ} \mathrm{C}$, with rainfall varied between 5 and $58 \mathrm{~mm}$, and photoperiod between $10.58 \pm 0.03$ and $12.58 \pm 0.20 \mathrm{~h}$. On the other hand, the variation of these parameters during rainy season ranged from $26.1 \pm 3.4$ to $30.6 \pm 1.9^{\circ} \mathrm{C}, 74-172 \mathrm{~mm}$, and $11.44 \pm 0.19$ $13.42 \pm 0.03 \mathrm{~h}$, respectively (Table 2 ). Contribution of the parameters 'rainfall' and 'season' on breeding pattern of $P$. armatus was not significant (multiple regression stepwise: rainfall: $t=-1.44, p=0.210$; season: $t=-2.39, p=0.062$ ); thus, both variables were removed from the final model. The resulting model explained $77.9 \%$ of the variability observed, showing a significant relationship between ovigerous females and the temperature/photoperiod (ANOVA test: $F=12.36, \mathrm{df}=9, p=0.005$ ). Temperature and photoperiod were related, respectively, in a direct and inverse way to the occurrence of breeding females of $P$. armatus. Indeed, the slopes of these parameters in the resulting multiple regression model showed positive and negative values, respectively (Slopes, temperature: 3.02, photoperiod: -3.69). By contrast, recruitment intensity was not correlated with environmental parameters, accounting for less than $30 \%$ of the observed variation in recruits (ANOVA: $F=0.54, \mathrm{df}=9, p=0.713$ ). 


\section{Males}
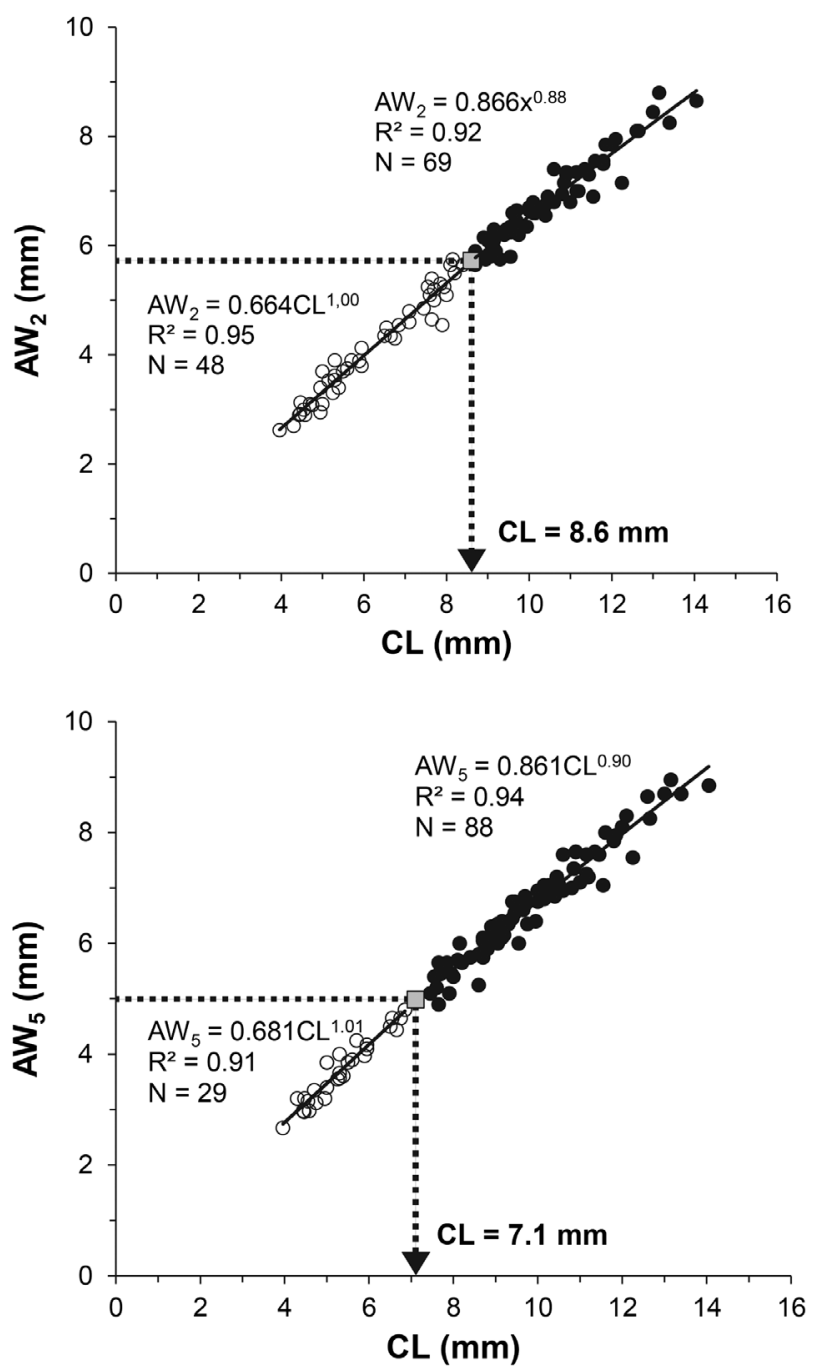

Females
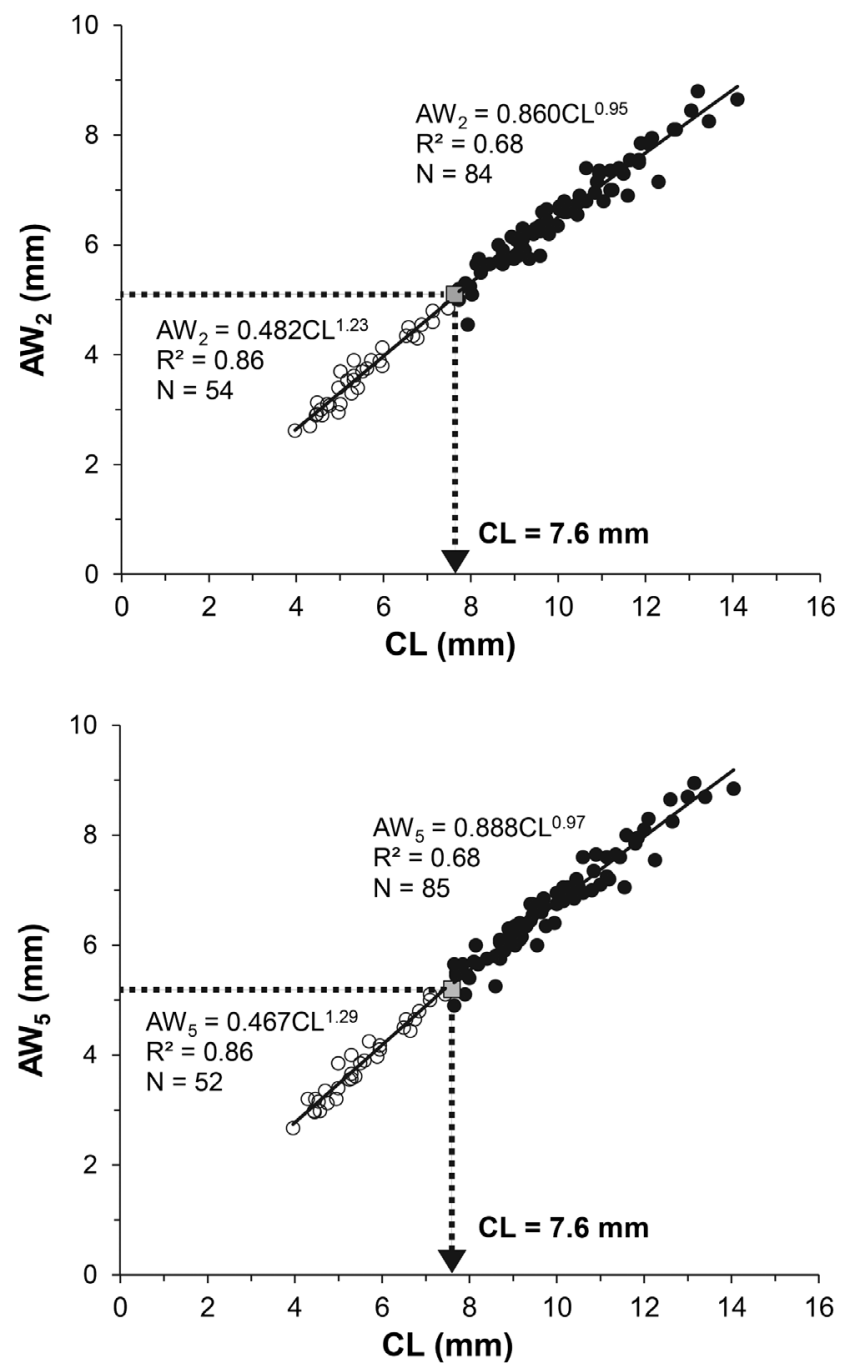

Figure 3. Relationships involving abdominal width (AW2, 2nd segment; and AW5, 5th segment) vs. carapace length (CL), in males and females of Petrolisthes armatus, and respective equations to each development phase (juvenile and adult), with indicative of the size at morphological maturity.

\section{Fecundity}

Fecundity was analyzed for 66 females with eggs in initial embryonic phase out of the 83 ovigerous females collected. In these females, fecundity ranged between 24 and 654 eggs ( $228 \pm 163$ eggs). A positive correlation was statistically confirmed between $\mathrm{NE}$ and $\mathrm{CL}$ in females of P. armatus (Pearson correlation: $r=0.85, p=0.0001$ ). Indeed, the relationship of $N E \times C L$ gave a good fit to empirical points $\left(R^{2}=0.72\right)$ in a representative mathematical equation to be used in the conversion between these variables. The slope $(b)$ of this relationship was significantly different from three $(t=12.78, p=0.0001)$, which means that fecundity was positive allometric (Figure 5 ).

\section{Discussion}

Ubatuba has been frequently used as natural scenery to study of a series of marine decapod populations from the coast of Brazil (e.g. Pinheiro \& Fransozo 1993, 1998, 2002; Bertini \& Fransozo 1999; Mantelatto \& Martinelli 2001), due to be considered yet an example of a pristine natural area (Mantelatto \& Fransozo 2000). Here, we present the first information about the life-history traits of $P$. armatus in Ubatuba Municipality. These results were compared to those obtained from other populations of porcellanid crabs of the South American coast (e.g. Lardies \& Wehrtmann 1996; Hattori \& Pinheiro 2001; Hernáez 2001; Hernáez \& Palma 2003), including other populations of the large 


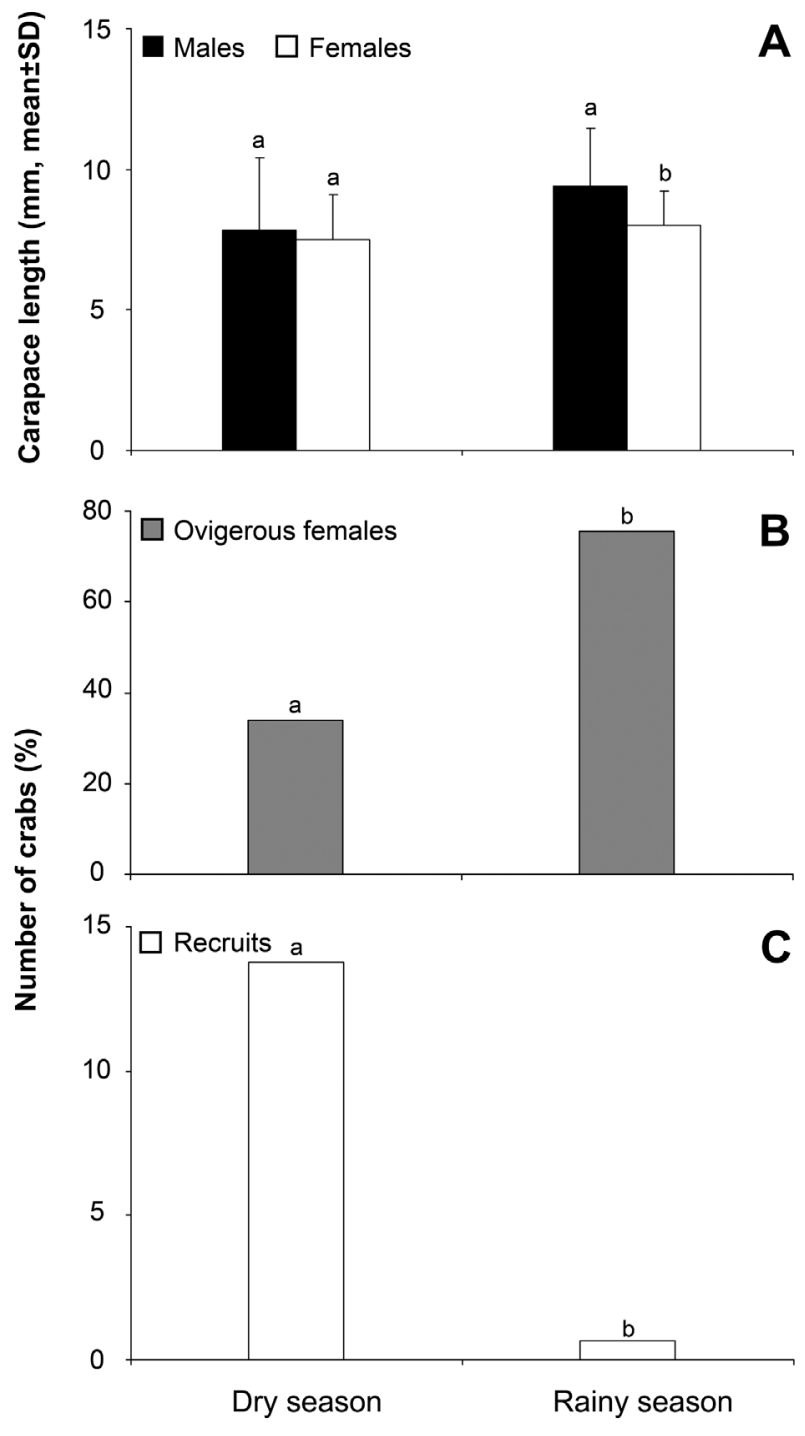

Figure 4. Size of each sex (A), percentage of ovigerous females (B) and recruits $(C)$ in each climatic season (dry: May to October; and rainy: November to April), of the porcelain crab Petrolisthes armatus at Praia Grande, São Paulo State, Brazil.

Table 2. Mean values of water temperature, rainfall, and photoperiod in at intertidal zone of Praia Grande, Ubatuba region (SP), Brazil. Values summarize readings obtained from August/1996 to July/1997.

\begin{tabular}{lcccc}
\hline Month/Year & Temperature $\left({ }^{\circ} \mathrm{C}\right)$ & Rainfall $(\mathrm{mm})$ & Photoperiod $(\mathrm{h})$ & Season \\
\hline August/1996 & 24.1 & 5 & 11.21 & Dry \\
September & 25.9 & 39 & 11.88 & Dry \\
October & 25.8 & 31 & 12.58 & Dry \\
November & 26.1 & 74 & 13.15 & Rainy \\
December & 28.3 & 117 & 13.42 & Rainy \\
January/1997 & 27.8 & 172 & 13.27 & Rainy \\
February & 30.2 & 120 & 12.79 & Rainy \\
March & 30.6 & 122 & 12.14 & Rainy \\
April & 28.5 & 110 & 11.44 & Rainy \\
May & 24.8 & 33 & 10.86 & Dry \\
June & 24.8 & 58 & 10.58 & Dry \\
July & 23.5 & 41 & 10.71 & Dry \\
\hline
\end{tabular}

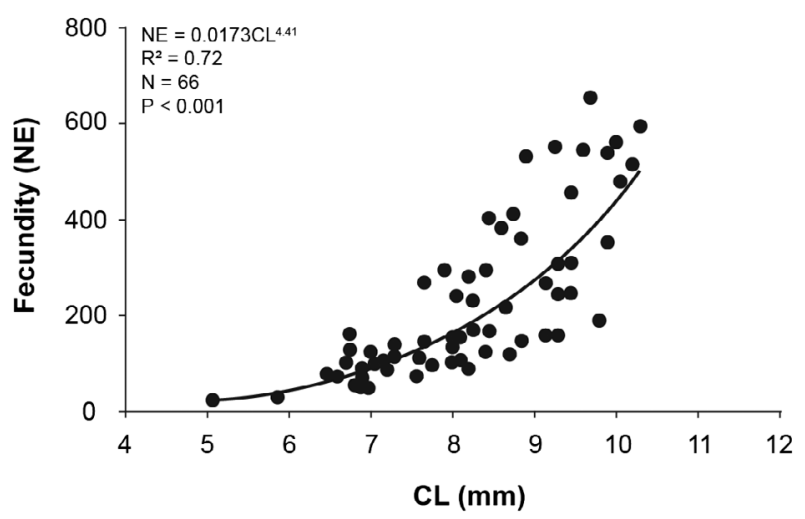

Figure 5. Fecundity relationship involving number of eggs (NE) vs. carapace length $(\mathrm{CL})$, of the porcelain crab Petrolisthes armatus at Praia Grande, São Paulo State, Brazil.

metapopulation of $P$. armatus along the Brazilian coast, where information about population traits is available (e.g. Miranda \& Mantelatto 2009).

Analysis of population structure of $P$. armatus at Ubatuba identifies three and two cohorts for males and females, respectively. This result partially coincides with the bimodal distribution reported by Miranda and Mantelatto (2009) for a population of this species from São Sebastião, about to $80 \mathrm{~km}$ at north from Ubatuba. In Ubatuba, $P$. armatus exhibited an unbiased sex ratio, without statistical difference between frequency of males and females in overall sample. This result agrees with the expected pattern under Fisher's theory where natural selection favors an equal frequency of males and females (Fisher 1930). Also, our finding is in agreement with another populations of $P$. armatus from the Brazilian coast where sex ratio did not differ from the expected 1:1 (Oliveira \& Masunari 1995; Miranda \& Mantelatto 2009). Analysis of sex ratio as a function of size indicated that males outnumber females in the two size classes below $5 \mathrm{~mm}$ (14 and 2, respectively). Considering that natural selection favors a 1:1 parental expenditure on offspring of the two sexes (Fisher 1930), our results suggest the possible existence of a differential mortality and/or a differential growth rate between sexes during the early benthic stage in $P$. armatus. According to Wenner (1972), a high mortality rate may affect selectively smaller females, but not males, due to different capabilities to escape, or the females could grow more quickly than males at that size, thus reducing the likelihood of being recorded during processing of the specimens. We assume that the absence of females in smaller size classes is due to natural selection against females during the early benthic stages of $P$. armatus. This assumption is supported by the findings reported by Oliveira and Masunari (1995), where they found a high frequency of males below $5 \mathrm{~mm}$ with a sex ratio biased 
toward males for smaller sizes. Also, the present study revealed a prevalence of males in higher size classes than females (14.1 and $10.3 \mathrm{~mm} \mathrm{CL}$, respectively). Summarizing, the sex ratio as a function of body size, with the prevalence of males in smaller and higher size classes, and the high proportion of females at intermediate size classes (5.1$10.0 \mathrm{~mm} \mathrm{CL}$ ), followed the Standard pattern (see Wenner 1972), corroborating results previously obtained by Miranda and Mantelatto (2009) for this species.

Hartnoll (1974, 1978, 1982, and 2001) was a pioneer in studies about the relative growth of brachyuran crabs. Patterns revealed by this author have been used as basal information and compared with a few studies available on relative growth for anomurans (Biagi \& Mantelatto 2006; Bueno \& Shimizu 2009; Hermoso-Salazar \& SanvicenteAñorve 2011; Ríos-Elósegui \& Hendrickx 2015), where porcellanid crabs remain as a non representative group, due to their reduced size and minor economic importance. This fact prevents more effective comparisons, particularly for the Porcellanidae family, the same occurring with other populations in relation to reproductive parameters, all useful for conservation purposes.

According to Miranda and Mantelatto (2010), anomurans have a high diversity of relative growth patterns among crustaceans, even when considering the scarce number of studies on Anomura. It is important to highlight that P. armatus was previously studied by these authors in other areas of São Paulo State, with divergent points verified between these populations. A common pattern informed by Richard Hartnoll in brachyuran males is a higher propodus chelar size in adults in relation to body size, generally representing a expressive growth rate during ontogeny, which can be used to estimate the size at onset of morphological maturity (Pinheiro \& Fransozo 1998). But this fact was not confirmed in males of $P$. armatus, where all measures registered in the chelar segment $(\mathrm{PL}, \mathrm{PH}$, and PW) showed a large positive allometry $(1.29 \leq b \leq 1.41)$ in relation to body size, but without changes during ontogeny and represented by only one equation to this sex in each chelar biometric relationship. However, a higher allometric growth constant in these chelar propodus variables was registered by Miranda and Mantelatto (2010) in males, revealing a larger size for these appendages. This same growth pattern was reported for other anomuran hermit crabs belonging to Diogenidae (e.g. Petrochirus diogenes by Bertini \& Fransozo 1999; and Loxopagurus loxochelis by Mantelatto \& Martinelli 2001). The chelipeds in males of infraorder Brachyura are morphological adaptations to select mates and to manipulate female during copulation (Pinheiro \& Fransozo 1993, 1999). The same occurs with crustaceans of the infraorder Anomura, where larger chelipeds are useful during antagonistic interactions with other males, as reported by Turra (2005) for hermit crab Pagurus criniticornis (Paguridae), and for the porcellanid crab Petrolisthes spinifrons, according to Baeza and Asorey (2012).

Both relationships of abdominal width $\left(\mathrm{AW}_{2}\right.$ and $\left.\mathrm{AW}_{5}\right)$ present a marked reduction of allometric growth rate, regardless of sex, but with a divergent pattern in males (isometry to negative allometry) when compared to females (positive allometry to isometry). The allometric reduction in porcelain crabs occurs because the abdomen is used for swimming during the juvenile phase, while adults are benthic, living in cavities under rocks, as well as inside galleries found in sandy reefs of sabellariid polychaetes. In addition, the abdomen in anomuran crabs is used similarly as in brachyuran crabs: to fix and protect pleopods (males) or egg mass (females) (Pinheiro \& Fransozo 1993). In males, the morphological maturity size based on abdomen variables occurred between 7.1 and $8.6 \mathrm{~mm} \mathrm{CL}$, due to the presence of one pleopod pair in the second somite $\left(\mathrm{AW}_{2}\right)$ and the absence of pleopods attached to the fifth somite $\left(\mathrm{AW}_{5}\right)$, respectively. According, we can indicate $7.1 \mathrm{~mm} \mathrm{CL}$ as the most reliable measure to represent maturity size in males due to an integrative growth between $\mathrm{AW}_{2}$ and gonopods in this sex. Therefore, future studies focusing on gonopod measure as a function of size $C L$ could be used to estimate sexual maturity. Otherwise, morphological maturity in females occurred at $7.6 \mathrm{~mm} \mathrm{CL}$ was very similar to puberty size of males (7.1 $\mathrm{mm} \mathrm{CL}$ ), while ovigerous females started at $5.1 \mathrm{~mm} \mathrm{CL}$, indicating a smaller physiological maturity size. A literature review indicates $15.1 \mathrm{~mm} \mathrm{CL}$ as the maximum body size reached by P. armatus, corresponding to $47.0-50.3 \%$ of the estimated morphological maturity size obtained in present study. In addition, the present study confirms a similar variation of body size $C L$ for each sex, when compared to values obtained by Miranda and Mantelatto (2010), also representing well the individuals in each size class. However, these authors indicated that chelar propodus relationships could reveal allometric growth changes during ontogeny, a fact not confirmed in the present study, where the same statistical protocol was used to estimate morphological maturity, using three chelar propodus variables ( $\mathrm{PL}, \mathrm{PH}$, and $\mathrm{PW}$ ). Furthermore, Miranda and Mantelatto (2010) used CW as independent variable, and the estimated puberty sizes were lower (males: $3.5 \mathrm{~mm}$ CW; females: $4.5 \mathrm{~mm} \mathrm{CW}$ ), corresponding to 23.2 and $29.8 \%$ of the maximum size in this species, respectively.

P. armatus at Praia Grande (Ubatuba) showed a yearround reproduction with ovigerous females collected throughout the entire study period. Reproductive activity in this species is mainly related to temperature oscillations which is in agreement with the reproductive pattern reported for organisms from tropical to subtropical regions where elevated seawater temperatures favor a continuous gonadal development and embryo production (Sastry 1983; Hartnoll \& Gould 1988; Bauer 1989; Costa \& Fransozo 
2004; Vergamini \& Mantelatto 2008; Hernáez et al. 2012; Silva et al. 2016).

Our data also match with the continuous reproductive pattern reported for other populations of $P$. armatus distributed along the Southeast Brazilian coast (Farol Island, Paraná $25^{\circ} 51^{\prime} \mathrm{S}, 48^{\circ} 32^{\prime} \mathrm{W}$ : Oliveira \& Masunari 1995; São Vicente, São Paulo $23^{\circ} 59^{\prime} \mathrm{S}, 46^{\circ} 22^{\prime} \mathrm{W}$ : Micheletti-Flores \& Negreiros-Fransozo 1999; Araçá, São Paulo 2348' S, 4524' W: Miranda \& Mantelatto 2009), thus revealing the establishment of a common reproductive pattern for all populations of this species in the Brazilian coast. Similarly, our work on breeding periodicity for $P$. armatus follows the reproductive pattern reported in most of the intertidal porcellanid crabs in which the general trend is to breed continuously throughout the year (Petrolisthes politus: Scelzo 1985; P. cinctipes: Boolootian et al. 1959; P. elongates: Jones 1977; Porcellana sayana: Meireles 2006).

Even though reproduction was continuous, proportion of brooding females in $P$. armatus were especially high during the rainy season, when temperature, rainfall and photoperiod were greater than dry season. Conversely, recruitment was almost inexistent during rainy season but extremely intense during dry season or when was recorded a notorious diminishing in these environmental parameters. According to information published in literature, this increment allow to initiate/intensify reproductive processes in coastal species of decapods (Hartnoll \& Gould 1988; Varadharajan et al. 2013), including an elevation of primary productivity induced by the increment of daylight period and the increasing in water discharge provoked by the intense rainfall. Therefore, in accordance with the previous information, the reproductive activity in P. armatus would be mainly induced by the increase of the seawater temperature, rainfall and photoperiod, which also favors the embryos incubation and the subsequent larval releasing in this species.

On the other hand, as has already been mentioned, the recruitment in $P$. armatus would be occurring during the reduction of seawater temperature, rainfall and photoperiod at Ubatuba. According to Gore (1970), P. armatus completes their larval development in about to $15-18$ days at $28{ }^{\circ} \mathrm{C}$, which in accordance with our information on the presence of brooding females, should reflect in a continuous recruitment pattern for this species in this place. However, our data indicated that recruitment in $P$. armatus is strongly seasonal. Unfortunately, our observations do not allow further conclusions about the environmental cues involved in the recruitment pattern of $P$. armatus at Ubatuba. We argue in favors of additional long-term studies in this species to reveal the environmental factors that induce to the recruitment in P. armatus.
Concentration of pollutant can vary according to season, with a reduction of lixiviation of pollutants from terrestrial areas to river, estuaries and to ocean, mainly during the dry season (Islam et al. 2015). The historical anthropogenic region of São Sebastião (SP) can explain the absence of recruits during dry season, as reported by Miranda and Mantelatto (2009), possibly due to a higher concentration of organic pollutants and other xenobiotics commonly used in oil tanks and found in that region. However, in Ubatuba SP, the population of $P$. armatus lives in a pristine habitat, without anthropic activity. Pollutants can affect negatively growth and reproduction of crustaceans, including alteration of sex ratio by organic pollutants, producing abnormal secondary sexual characters in these animals (see review by Rodríguez et al. 2007). The influence of pollutants can explain the size at maturity and modal growth differences verified in this study, when compared with those obtained in polluted area by Miranda and Mantelatto (2009). An increase in fecundity related to female size is a pattern among decapod crustaceans, but in equatorial regions (e.g. Pacific Costa Rica), P. armatus can produce three times more eggs when compared to equally sized females from Southern Brazil (Wehrtmann et al. 2012). In respect to production of eggs, $P$. armatus had a high variation of the fecundity since $7.5 \mathrm{~mm} \mathrm{CL}$, coincident to maturity size in females, possibly related to primiparous or multiparous females during the studied period. Population biology can reveal interesting information, involving complex responses, which many times are difficult to quantify. In this respect, Ford et al. (2003) conducted studies in the laboratory and in the field, showing that fecundity/fertility can be affected by a variety of different contaminants. This effect was not tested in the present study but indicates other variation source that affects biologic parameters such as metabolic rate, growth and reproduction, need to be evaluated when possible. In this fact, Ubatuba is a Brazilian coastal region where environmental quality is maintained yet, assuring basal characteristics to better population development.

\section{Disclosure statement}

No potential conflict of interest was reported by the authors.

\section{References}

Alvares CA, Stape JL, Sentelhas PC, Gonçalves JLM, Sparovek G. 2013. Köppen's climate classification map for Brazil. Meteorologische Zeitschrift [Meteorological Journal]. 22:711-728.

Angilletta MJ Jr, Dunham AE. 2003. The temperature - size rule in ectotherms: simple evolutionary explanations may not be general. The American Naturalist. 162:332-342. 
Atkinson D, Sibly RM. 1997. Why are organisms usually bigger in colder environments? making sense of a life history puzzle. Trends in Ecology \& Evolution. 12:235-239.

Baeza JA, Asorey CM. 2012. Testing the role of male-male competition in the evolution of sexual dimorphism: a comparison between two species of porcelain crabs. Biological Journal of the Linnean Society. 105:548-558.

Bauer RT. 1989. Continuous reproduction and episodic recruitment in nine shrimp species inhabiting a tropical seagrass meadow. Journal of Experimental Marine Biology and Ecology. 127:175-187.

Bertini G, Fransozo A. 1999. Relative growth of Petrochirus diogenes (Linnaeus, 1758) (Crustacea, Anomura, Diogenidae) in the Ubatuba region, São Paulo. Brazil Revista Brasileira de Biologia [Brazilian Journal of Biology]. 59:617-625.

Biagi R, Mantelatto FLM. 2006. Relative growth and sexual maturity of the hermit crab Paguristes erythrops (Anomura, Diogenidae) from South Atlantic. Hydrobiologia. 559:247254.

Boolootian RA, Giese AC, Farmanfarmaian A, Tucker J. 1959. Reproductive cycles of five west coast crabs. Physiological Zoology. 32:213-220.

Brante A, Cifuentes S, Pörtner HO, Arntz W, Fernández M. 2004. Latitudinal comparisons of reproductive traits in five brachyuran species along the Chilean coast. Revista Chilena de Historia Natural [Chilean Journal of Natural History]. 77:15-27.

Bueno SLS, Shimizu RM. 2009. Allometric growth, sexual maturity, and adult male chelae dimorphism in Aegla franca (Decapoda: Anomura: Aeglidae). Journal of Crustacean Biology. 29:317-328.

Caine EA. 1975. Feeding and masticatory structures of selected Anomura (Crustacea). Journal of Experimental Marine Biology and Ecology. 18:277-301.

Costa RC, Fransozo A. 2004. Reproductive biology of the shrimp Rimapenaeus constrictus (Decapoda, Penaeidae) in the Ubatuba region of Brazil. Journal of Crustacean Biology. 24:274-281.

Defeo O, Cardoso RS. 2002. Macroecology of population dynamics and life history traits of the mole crab Emerita brasiliensis in Atlantic sandy beaches of South America. Marine Ecology Progress Series. 239:169-179.

Ferreira LA. 2015. Intersexuality in the porcellanid crab Pisidia longicornis (Crustacea: Decapoda: Anomura: Porcellanidae). Zoologia [Zoology]. 32:176-178.

Fisher RA .1930. The genetical theory of natural selection. Oxford: Claredon Press.

Ford AT, Fernandes TF, Rider SA, Read PA, Robinson CD, Davies IM. 2003. Measuring sublethal impacts of pollution on reproductive output of marine Crustacea. Marine Ecology Progress Series. 265:303-309.

Gayanilo FC, Sparre P, Pauly D. 1996. Stock assessment tools: user's guide. Rome: FAO ICLARM.

Gore RH. 1970. Petrolisthes armatus: A redescription of larval development under laboratory conditions (Decapoda, Porcellanidae). Crustaceana. 18:75-89.

Haig J. 1956. The Galatheidea (Crustacea, Anomura) of the Allan Hancock Atlantic expedition with a review of the Porcellanidae of the western North Atlantic. Allan Hancock Atlanta Express. 8:1-45.

Hartnoll RG. 1974. Variation in growth pattern between some secondary sexual characters in crabs (Decapoda Brachyura). Crustaceana. 27:131-136.
Hartnoll RG. 1978. The determination of relative growth in crustacea. Crustaceana. 34:281-293.

Hartnoll RG. 1982. The biology of Crustacea: embriology, morphology and genetics. In: Bliss DE, editor. Growth. New York, NY: Academic Press; p. 111-196.

Hartnoll RG. 2001. Growth in Crustacea - twenty years on. Hydrobiologia. 449:111-122.

Hartnoll RG, Gould P. 1988. Brachyuran life history strategies and the optimization of egg production. In: Fincham AA, Rainbow PS, editors. Aspects of Decapod Crustacean Biology. Oxford: Clarendon Press; p. 1-9.

Hattori GY, Pinheiro MAA. 2001. Fecundity and embryology of Pachycheles monilifer (Dana, 1852) (Crustacea, Anomura, Porcellanidae) in Praia Grande Beach, Ubatuba (SP), Brazil. Nauplius. 9:97-109.

Hermoso-Salazar M, Sanvicente-Añorve L. 2011. Relative growth of the land hermit crab Coenobita clypeatus (Anomura, Coenobitidae) from a coral reef island, southern Gulf of Mexico. Crustaceana. 84:689-699.

Hernáez P. 2001. Producción y rendimiento reproductivo en Petrolisthes granulosus (Decapoda, Anomura, Porcellanidae) en diferentes localidades del norte de Chile: una comparación latitudinal [Production and reproductive performance of Petrolisthes granulosus (Decapoda, Anomura, Porcellanidae) in different areas in northern Chile: a latitudinal comparison]. Investigaciones Marinas [Marine Research]. 29:73-81.

Hernáez P. 2014. Estado taxonômico e história de vida de Callichirus seilacheri (Bott, 1955) (Decapoda, Axiidea, Callianassidae) na costa do Pacífico Leste:ecologia reprodutiva em ambientes tropicais e relação entre a abundância e a variabilidade latitudinal dos atributos populacionais na costa do Chile [Taxonomic status and life history of Callichirus seilacheri (Bott, 1955) (Decapoda, Axiidea, Callianassidae) on the coast of the Eastern Pacific: reproductive ecology in tropical environments and relationship between abundance and latitudinal variability of population attributes on the coast of Chile] [PhD thesis]. São Paulo (BR): Universidade de São Paulo.

Hernáez P, Palma S. 2003. Fecundidad, volumen del huevo y rendimiento reproductivo de cinco especies de porcelánidos intermareales del norte de Chile (Decapoda, Porcellanidae) [Fecundity, egg volume and reproductive performance of five intertidal porcelain species from northern Chile (Decapoda, Porcellanidae)]. Investigaciones Marinas [Marine Research]. 31:35-46.

Hernáez P, Wehrtmann IS. 2007. Population biology of the burrowing shrimp Callichirus seilacheri (Decapoda: Callianassidae) in northern Chile. Revista de Biología Tropical. 55:141-152.

Hernáez P, Villegas-Jiménez E, Villalobos-Rojas F, Wehrtmann IS. 2012. Reproductive biology of the ghost shrimp Lepidophthalmus bocourti (A. Milne-Edwards, 1870) (Decapoda: Axiidea: Callianassidae): A tropical species with a seasonal reproduction. Marine Biology Research. 8:635-643.

Ihaka R, Gentleman R. 1996. R: a language for data analysis and graphics. The Journal of Computational and Graphical Statistics. 5:299-314.

Islam M, Uddin M, Tareq S, Shammi M, Kamal A, Sugano T, Kurasaki M, Saito T, Tanaka S, Kuramitz H. 2015. Alteration of water pollution level with the seasonal changes in mean daily discharge in three main rivers around Dhaka City, Bangladesh. Environments. 2:280-294. 
Jones MB. 1977. Breeding and seasonal population changes of Petrolisthes elongatus (Crustacea, Decapoda, Anomura) at Kaikoura, New Zealand. Journal of the Royal Society of New Zealand. 7:259-272.

Lardies MA, Wehrtmann IS. 1996. Aspects of the reproductive biology of Petrolisthes laevigatus (Guérin, 1835) (Decapoda: Anomura:Porcellanidae). I. Reproductive output and chemical composition of eggs during embryonic development. Archive of Fishery and Marine Research. 43:121-135.

Levins R. 1969. Some demographic and genetic consequences of environmental heterogeneity for biological control. Bulletin of the Entomological Society of America. 15:237-240.

Mantelatto FLM, Fransozo A. 2000. Brachyuran community in Ubatuba Bay, northern coast of São Paulo State. Brazil Journal of Shellfish Research. 19:701-709.

Mantelatto FLM, Martinelli JM. 2001. Relative growth and sexual dimorphism of the South Atlantic hermit crab Loxopagurus loxochelis (Anomura, Diogenidae) from Ubatuba. Journal of Natural History. 35:429-437.

Mantelatto FL, Pileggi LG, Miranda I, Wehrtmann IS. 2011. Does Petrolisthes armatus (Anomura, Porcellanidae) form a species complex or are we dealing with just one widely distributed species? Zoological Studies. 50:372-384.

Marascuilo LA, McSweeney M. 1977. Nonparametric and distribution-free methods for the social sciences. Monterey, CA: Brooks/Cole Publishing.

McLaughlin PA. 1980. Comparative morphology of recent Crustacea. San Francisco: W.H. Freeman.

Meireles AL. 2006. Estudo comparativo da distribuição espaçotemporal, da estrutura populacional e da relação de simbiose entre o ermitão Dardanus insignis (de Saussure, 1858) (Anomura, Diogenidae) e o porcelanídeo Porcellana sayana (Leach, 1820) (Anomura, Porcellanidae) no litoral norte paulista [Comparative study of the spatiotemporal distribution, population structure and symbiosis relationship between the hermit Dardanus insignis (de Saussure, 1858) (Anomura, Diogenidae) and the porcellain Porcellana sayana (Leach, 1820) (Anomura, Porcellanidae) on the north coast Paulista] [dissertation]. Ribeirão Preto (SP): University of São Paulo.

Melo GAS. 1999. Manual de identificação dos Crustacea Decapoda do litoral brasileiro: Anomura, Thalassinidea, Palinuridea, Astacidea [Manual of identification of crustaceans decapoda of the Brazilian coast: Anomura, Thalassinidea, Palinuridea, Astacidea]. São Paulo: Plêiade/FAESP.

Micheletti-Flores CV, Negreiros-Fransozo ML. 1999. Porcellanid crabs (Crustacea, Decapoda) inhabiting sand reef built by Phragmatopoma lapidosa (Polychaeta, Sabellariidae) at Paranapuã beach, São Vicente, SP. Brazil Revista Brasileira de Biologia [Brazilian Journal of Biology]. 59:63-73.

Miranda I, Mantelatto FL. 2009. Estimating population features of the anomuran crab Petrolisthes armatus (Porcellanidae) in a remaining and impacted mangrove area of western Atlantic. Journal of Natural History. 43:2027-2039.

Miranda I, Mantelatto FL. 2010. Sexual maturity and relative growth of the porcellanid crab Petrolisthes armatus (Gibbes, 1850) from a remnant mangrove area southern Brazil. Nauplius. 18:87-93.

Nicol EAT. 1932. The feeding habits of the Galatheidea. Journal of the Marine Biological Association of the United Kingdom. 18:87-106.

Oliveira E, Masunari S. 1995. Estrutura populacional de Petrolisthes armatus (Gibbes) (Decapoda, Anomura, Porcellanidae) da Ilha do Farol, Matinhos, Paraná [Population structure of Petrolisthes armatus (Gibbes) (Decapoda, Anomura, Porcellanidae) from Lighthouse Island, Matinhos, Paraná, Brazil]. Revista Brasileira de Zoologia [Brazilian Journal of Zoology]. 12:355-371.

Oliveira DB, Silva DC, Martinelli-Lemos JM. 2013. Larval and adult density of the porcellanid crab Petrolisthes armatus (Anomura: Porcellanidae) in an Amazon estuary, northern Brazil. Zoologia [Zoology]. 30:592-600.

Osawa M, Mclaughlin PA. 2010. Annotated checklist of anomuran decapod crustaceans of the World (exclusive of the Kiwaoidea and families Chirostylidae and Galatheidae of the Galatheoidea). Part II - Porcellanidae. The Raffles Bulletin of Zoology. 23:109-129.

Petriella AM, Boschi EE. 1997. Crecimiento en crustáceos decápodos: resultados de ivestigaciones realizadas em Argentina [Growth in decapod crustaceans: results of research carried out in Argentina]. Investigaciones Marinas Valparaíso [Marine Research Valparaíso]. 25:135-157.

Pinheiro MAA, Fransozo A. 1993. Relative growth of the speckled swimming crab Arenaeus cribrarius (Lamark, 1818) (Brachyura, Portunidae), near Ubatuba, State of São Paulo, Brazil. Crustaceana. 65:377-389.

Pinheiro MAA, Fransozo A. 1998. Sexual maturity of the speckled swimming crab Arenaeus cribarius (Lamarck, 1818) (Decapoda: Brachyura: Portunidae), in the Ubatuba litoral, São Paulo State, Brazil. Crustaceana. 7:434-452.

Pinheiro MAA, Fransozo A. 1999. Reproductive behavior of the swimming crab Arenaeus cribarius (Lamarck, 1818) (Decapoda: Brachyura: Portunidae) in captivity. The Bulletin of Marine Science. 64:243-253.

Pinheiro MAA, Fransozo A. 2002. Reproduction of the speckled swimming crab Arenaeus cribrarius (Brachyura: Portunidae) on the Brazilian coast near $23^{\circ} 30^{\prime} \mathrm{S}$. Journal of Crustacean Biology. 22:416-428.

Pinheiro MAA, Hattori GY. 2006. Relative growth of the mangrove crab Ucides cordatus (Crustacea, Brachyura, Ocypodidae) at Iguape (SP). Brazilian Archives of Biology and Technology. 49:813-823.

Ríos-Elósegui D, Hendrickx ME. 2015. Abundance, relative growth and fecundity of Emerita rathbunae Schmitt, 1935 (Decapoda, Anomura, Hippidae) in the S.E. Gulf of California. Crustaceana. 88:127-143.

Rivadeneira MM, Hernáez P, Baeza JA, Boltaña $S$, Cifuentes $M$, Correa C, Cuevas A, del Valle E, Hinojosa I, Ulrich N, Valdivia N, Vásquez N, Zander A, Thiel M. 2010. Testing the abundantcentre hypothesis using intertidal porcelain crabs along the Chilean coast: linking abundance and life-history variation. Journal of Biogeography. 37:408-486.

Rodríguez EM, Medesani DA, Fingerman M. 2007. Endocrine disruption in crustaceans due to pollutants: a review. Comparative Biochemistry and Physiology Part A: Molecular \& Integrative Physiology. 146:661-671.

Sastry AN. 1983. Ecological aspects of reproduction. In: Vernberg FJ, Vernberg WB, editor. The Biology of Crustacea. Vol. 8 - Environmental adaptations. New York, NY: Academic Press; p. 179-270.

Scelzo MA. 1985. Biologia y morfometria del cangrejo Petrolisthes politus (Gray, 1831) (Anomura, Porcellanidae) de la Isla Cubagua, Venezuela [Biology and morphometry of the crab Petrolisthes politus (Gray, 1831) (Anomura, Porcellanidae) of Cubagua Island, Venezuela]. Boletín del Instituto Oceanográfico. Universidad de Oriente [Bulletin of the Oceanographic Institute. Eastern University]. 24:63-74. 
Silva AR, Wolf MR, Castilho AL. 2016. Reproduction, growth and longevity of the endemic South American crab Aegla marginata (Decapoda: Anomura: Aeglidae). Invertebrate Reproduction \& Development. 60:59-72.

Sokal RR, Rohlf FJ. 1995. Biometry: the principle and practice of statistics in biological research. New York, NY: Freeman WH.

Somers K. 1991. Crustacean egg production. In: Schram FR, Balkema AA, editors. Characterizing size-specific fecundity in crustaceans. Rotterdam: The Netherlands; p. 357-378.

Somerton DA. 1980. A computer technique for estimating the size of sexual maturity in crabs. Canadian Journal of Fisheries and Aquatic Sciences. 37:1488-1494.

Somerton DA, Macintosh RA. 1983. The size at sexual maturity of blue king crab, Paralithodes platypus, in Alaska. Fishery Bulletin. 81:621-628.

Souza-Carvalho EA, Carvalho FL, Couto ECG. 2011. Maturidade sexual em Callinectes ornatus Ordway, 1834 (Crustacea: Decapoda: Portunidae) no Litoral de Ilhéus, BA, Brazil [Sexual maturity in Callinectes ornatus Ordway, 1834 (Crustacea: Decapoda: Portunidae) on the Littoral of Ilhéus, BA, Brazil]. Papéis Avulsos de Zoologia (São Paulo) [Avulsos roles of Zoology]. 51:367-372.

Turra A. 2005. Reproductive behavior of intertidal hermit crabs (Decapoda, Anomura) in southeastern Brazil. Revista Brasileira de Zoologia [Brazilian Journal of Zoology]. 22:313319.

Varadharajan D, Soundarapandian P, Pushparajan N. 2013. Effect of physico-chemical parameters on crabs biodiversity. Journal of Marine Science: Research \& Development. 3:1-11.

Varejão-Silva MA, Ceballos JC. 1982. Meteorologia Geral Coleção Politécnica 2 [General Meteorology. Polytechnic Collection 2]. Campina Grande: UFPb/CNP.

Vergamini FG, Mantelatto FL. 2008. Continuous reproduction and recruitment in the narrowback mud crab Panopeus americanus (Brachyura, Panopeidae) in a remnant humanimpacted mangrove area. Invertebrate Reproduction \& Development. 51:1-10.

Wehrtmann IS, Miranda I, Lizana-Moreno CA, Hernáez P, Barrantes-Echandi V, Mantelatto FL. 2012. Reproductive plasticity in Petrolisthes armatus (Anomura, Porcellanidae): a comparison between a Pacific and an Atlantic population. Helgoland Marine Research. 66:87-96.

Wenner A. 1972. Sex ratio as a function of size in marine crustacea. The American Naturalist. 106:321-350.

Werding B, Hiller A, Lemaitre R. 2003. Geographic and depth distributional patterns of western Atlantic Porcellanidae (Crustacea: Decapoda: Anomura), with an updated list of species. Memoirs of Museum Victoria. 60:79-85.

Wilson K, Hardy ICW. 2002. Sex ratios: concepts and research methods. In: Hardy ICW, editor. Statistical analysis of sex ratios: an introduction. Cambridge: Cambridge University Press; p. 48-92.

Zar JH. 2010. Biostatistical analysis. New Jersey: Prentice Hall. 